\title{
Kis Endre
}

az MTA doktora, Eötvös Loránd Tudományegyetem - ORZSE

\section{A szimmetria terei}

A címben jelzett fogalom egy új filozófiai-tudásszociológiai diszciplina körvonalait rejti magában. Az emberi gondolkodásban, fogalomalkotásban betöltött, jórészt máig is feltáratlannak megmaradó meghatározó és konstituáló jelentôsége miatt a szimmetria jelenségére új tudásszociológia épithetó. Ha a tudásszociológiát e fogalom széles értelmében a mindenkori tudás és különösen a filozófiai tudás társadalmi-történelmi megalapozásaként

fogjuk fel, a szimmetria jelenségét az itt szóba jöhetố lehetséges kauzalitások sorában különleges hely illetheti meg.

A sajátosan tudásszociológiai tudásmagyarázat nem az egyes kijelentésekhez vezető tárgyi vagy diszciplináris mozzanatokat veszi alapul, de e tárgyi vagy diszciplináris kereteken túlmutató, „,távolabbi” meghatározásokat és motívumokat, ezért volt olyannyira magától értetődő, hogy a filozófiának és általában a tudásnak ez a keresett meta-tudománya csak a ,szociológia” lehet.

Nyilvánvaló: a szimmetria-jelenségnek nagy esélyei vannak, hogy a szélesen értelmezett tudásszociológiában jelentős szerephez, esetleg önálló tudásszociológiai paradigma kialakításának esélyéhez juthasson. Az esélyek egyik szembeszökő oka éppen a szimmetria-jelenségnek a létező diszciplínáktól való rendkívüli távolsága.

A szimmetria-jelenség tudásszociológiai esélyeinek másik kiemelkedő összetevője, hogy egy ráépített tudásszociológia (vagy egy tudásszociológiai jellegű, kisebb általánosítású diszciplína) a tudásszociológiák mindeddig legmeghatározóbb alap-kiindulópontjától eltérő új kiindulópontot jelenthet.

A szimmetria-jelenségre épített tudásszociológia az előzetes megfontolások alapján három, önmagában is teljes és értelmes kérdésfeltevés egyesítéséből jöhetne létre:

Ami a szimmetriát, mint a gondolkodás, a filozófia egy valóban lényegesen meghatározó összetevőjét illeti, e tekintetben a legáltalánosabb megfogalmazandó összefüggés a szimmetriának mint tudásszociológiailag minősített antropomorfizációnak a felfogása. A szimmetria ezen az áttételes, s mindenképpen specifikusan tudásszociológiai úton-módon önálló elméletalkotó tényezővé növi ki magát, s elméletalkotásának iránya és alaptendenciája mindenképpen antropomorfizáló irányú.

A szimmetria jelensége a maga általánosságában azért tekinthető antropomorfnak, mert a gondolkodói tevékenység során lehetségessé váló szimmetria-viszonyok realizálása az esetek túlnyomó többségében ,,antropomorf” módon megy végbe. A lehetségessé váló szimmetria-viszonyok mintegy véget vetnek az aktuális megismerési folyamatnak, és olyan (elsősorban formális) keretben realizálódnak, amelyek már maguk válnak a további megismerési folyamat új keretévé.

A mindennapi tudat - amelynek szférájában természetesen az antropomorfizáció jelensége legitimnek, sőt, adekvátnak mondható - sokban megalapozója a tudományos megismerésnek, a szimmetria-jelenség pedig szerves összetevője. A mindennapi tudat müködésének alapelvei sokban szorosan is össze vannak fonódva a szimmetria-jelenséggel. 
Ezek közül az alapelvek közül most csak az ún. „spontán materializmus”-t említenénk, amelynek jegyében a mindennapi tudat elfogadja a konkrét és érzékelhető valóságot olyannak, amilyen (például a mindenkor sokak által megelölegezett spirituális vagy metafizikus tartalmakkal szemben), és amennyiben ez a számára konkrétan adott valóság messzemenően a szimmetria elvei alapján van berendezve, úgy (más hasonló tartalmakkal együtt) a szimmetriát is el fogja fogadni az ő számára lehetséges és legitim módon antropomorf szemléleten belül valóságosnak. Ugyanezt a beállítódást erősíti a mindennapi tudat funkcionálásának, valóság-feldolgozásának egy másik meghatározó alapelve, az ún. „spontán harmonisztika” is. Ez az alapelv a mindennapi tudatnak azt az ugyancsak vezető beállítódását ragadja meg, amely szerint a mindennapi tudat ugyan teljes súlyában fel tudja mérni a valóság dinamikus és konfliktuózus természetét, mégsem tud meglenni a harmonisztika, az univerzalizmus átfogó feltevése nélkül. Nos, a „spontán harmonisztika" így értelmezett meghatározó szerepe a mindennapi tudat funkcionálásában egyben egyet jelent a szimmetria jelenségének teljes elfogadásával.

A mindennapi tudat általános funkcionálásának van azonban még egy olyan vonása, amelyik épp a maga általánosságában, azaz még az egyes konkrét alapelvektöl is függetlenül elválaszthatatlanul köti össze a szimmetria-jelenséggel. Ez az átfogó jelenség, ami nélkül a mindennapi tudat valóságfeldolgozó funkciója gyakorlatilag annyira lehetetlen lenne, hogy az egyes konkrét alapelvek megfogalmazásához sem juthatnánk el, az analógia. Mivel az analógia, az analógiás gondolkodás bizonyos létező tartalmak, szerkezetek és fogalmak rövidre zárt, közvetlen, mindenképpen reflexió nélküli átvételét jelenti (miközben a reflexió hiánya a mindennapi tudat egyik meghatározó kritériuma), az analógiákkal átvett tartalmak eredeti szimmetria-viszonyai minden változás nélkül kerülhetnek a mindennapi tudat új tartalmai közé. Minden analógia minden szimmetria-viszonyának végső alapzata természetesen a test szimmetriája.

A nagy általánosságban antropomorfizáló hatásúnak nyilvánított szimmetria-jelenség kritikai tudásszociológiájának meghatározó összetevőjét jelentheti a szimmetria genealógiájának a (politikai) hatalom genealógiájával való összevetése.

A filozófiai tudásszociológia a korai újkortól kezdve tett már releváns hivatkozásokat az emberi tudás alapkategóriáinak a politikai hatalommal való kapcsolatára. Hatalmas ős-tudásszociológiai problematikát testesít meg például a humanizmus és a protestantizmus kritikus vitairat-irodalma, a maga módján egyetlen nagy tudásszociológiai kritikát testesített meg a felvilágosodás teoretikus és praktikus mozgalma, új felvirágzását hozta el ennek a gondolkodási iránynak a gyakorlatilag teljesen tudásszociológiai megalapozású újhegelianizmus, s mire szerves része lett a tudásszociológiai elem a Marxtól már jórészt függetlenül paradigmává váló „,marxizmus”-nak, már el is érte nagy nemzetközi sikerét a nietzsche-i ,új-felvilágosodás” tudásszociológiai paradigmája „,minden értékek átértékelésé"-vel. E hatalmas irányzatok (és sorozatos, sajátos ritmust követő reneszánszaik) mind tematizálták a maguk módján a tudás alaprendszereinek (posztmodernbe hajló kifejezéssel szólva: a „dolgok rendjé”-nek) és a politikai hatalomnak sajátosan genealogikus kapcsolatát.

Mindez azt is jelenti, hogy amennyiben a szimmetria-jelenség bármelyik változatban is része az adott tudás-alakzatoknak, természetes módon kerül kapcsolatba a politikai hatalommal, mint a társadalmi tudás konstitúciójának lehetséges kiindulópontjával.

Mindezek a nagy tudásszociológiai törekvések tudásszociológiai szempontból azonban mind összegezhetőek voltak a Mannheim Károly-i léthezkötöttség paradigmájában. Ez azt jelentette, hogy a tudás alapkategóriáinak a politikai hatalom révén történő konstitúciója, illetve elosztása e paradigmán belül csak a léthezkötöttség tételezésén keresztül volt lehetséges.

A léthezkötöttségen alapuló paradigma azonban nem annyira a tudás alapjainak meghatározásaiban, mint inkább a filozófiai (politikai) diszkusszióban alkalmazott „,ideoló- 
gia”-gyanú jelenségének előtérbe kerülésében játszott szerepet. Ez azzal a természetes következménnyel járt, hogy a szimmetria-jelenség már ebből az okból sem játszhatott komolyabb szerepet a léthez-kötöttségre alapozott tudásszociológiában, hiszen egy szimmetria-viszony feltételezése érdemileg sohasem lehetett ideológia-gyanú tárgya.

Ha el akarjuk hagyni a léthezkötöttségi paradigmát, két út áll előttünk. Egyrészt foglalkozhatunk általánosságban egy, a szimmetria-jelenséggel foglalkozó tudásszociológia felépítésének problematikájával, másrészt kísérletet tehetünk arra, hogy a nagyon kevés (közelebbről-távolabbról) nem léthezkötöttségi kiindulópontú tudásszociológián belül kíséreljük meg felmérni a szimmetria-jelenség helyét és szerepét.

A második lehetőséget előre véve, a nem-léthezkötöttségből kiinduló tudásszociológiai irányzatokat tekintve mindenképpen említésre kívánkozik a posztmodern gondolkodás kvázi-tudásszociológiai dimenziója, amelyen belül mindenképpen értelmesen lenne felvethető a szimmetria-jelenség tudásszociológiai megközelítése. A posztmodern gondolkodás radikálisan kitágította a tudásszociológiai gondolkodás, vagy ami azzal egyet jelent, a tudásszociológiai kritika körét, s ezzel ki is lépett a léthezkötöttségi paradigmán kívüli szellemi térbe.

A szimmetria-jelenség rendkívüli közelségben van az „ideológia” és a tiszta fogalmában vett „politikai hatalom” szférájához. A világ rendje, az érdekek harmóniája, a társadalmi szerkezet mind olyan képzetek, amelyek a viszonyok mindent meghatározó rendjét hivatottak megfogalmazni.

A társadalom ezen alapvető, magát a társadalmat és a társadalmiságot konstituáló rendjét (amely rendfogalom erre irányuló különleges elemzések nélkül is, mintegy önmagától elválik a társadalmi lét és reprodukció számos szintjén és szerkezeti pozíciójában megmutatkozó más és ugyancsak releváns rendfogalmaktól) olyan alapvető fogalmak is őrzik, mint a (magyarul sajnálatos módon így kifejezhetetlen) „Ordnungsmacht” vagy éppen a „rendtartó” székely falu, amelyeket teljességgel lehetetlen elképzelni a rend alapvető szimbolikus formái, így éppen a szimmetria-jelenség nélkül. Ezen a ponton tehát igazolódik a posztmodern tudás-genealógia.

A szimmetria-formában bizonyosan nem a társadalom valódi hatalmi viszonyrendszere képeződik le. Fenn és Lenn makulátlan fogalmi szimmetriát alkotnak, mégsem gondolhatja senki komolyan, hogy a fogalmi szimmetria, vagy bármely más szimmetria-viszony a fogalmak referencia-tartalmaira nézve igaz lehet. A történelem általunk ismert társadalmaiban a Fenn mindig jóval kisebb számú csoportot jelentett, mint a Lenn, s e két elem valóságos erőviszonyai minden módon leírhatók, csak éppen a szimmetria viszonyaként nem.

A minden közelebbi konkrét történeti és szociológiai vonástól megfosztott „hatalom” középponti szerepe meglehetős egyértelmüséggel utal ezen elmélet (kizárólagosnak semmiképpen sem tekinthető) új-baloldali eredetére. E nyomós történeti okokból eddig artikulálatlannak megmaradt új-baloldali eredet - paradox módon - egyszerre elönyöket és hátrányokat is jelent. Elönynek tekinthető a politikai hatalomnak az újbaloldali gondolkodásban konkretizált fogalmától való valamelyes elszakadása, azaz e hatalom egy új típusú fogalmának kidolgozása (amely épp a maga általánosságában már eredményesen tüntethető fel tudás-konstituáló erőként).

Hátránya e fogalomnak viszont éppen az, amit imént még előnyként tüntettünk fel. E hatalom-fogalom ugyanis olyan tartalmatlan, még spekulatívan sem meghatározott általánosságokban mozog, hogy majdhogynem lehetetlen fogalmi elemzése. Meg lehet ugyan nevezni a politikai hatalmat, mint a tudás alapzatainak végső meghatározóját, $\mathrm{s}$ ezzel mint a mindenkori tudás-alakzat genealógiájának valóságos eredetét, de magát az egész genealógiai folyamatot vagy annak releváns részeit nem lehet tudományos vagy filozófiai diskurzus tárgyává tenni. 
A végső magyarázatként való megnevezés esetleges legitimizálása éppen a hozzávezető út távolsága, ezen út tudományos bejárásának lehetetlensége miatt majdnem teljesen izomorf helyzetet hoz létre azzal, ahogy a posztmodern gondolkodás a léthezkötöttségi paradigmát abszolút módon kitágítja. Végső soron mérlegelhető ez a kitágítás (hiszen a mindannyiunk által használt formális logika is tárgyává tehető egy ilyen radikális kitágításnak), de ennek éppen abszolút jellege szünteti meg a tudományos vagy a filozófiai kutatás valódi terepét (s ezzel voltaképpeni tárgyát is).

A szimmetria-jelenség filozófiai kritikájának (ami mindig egy, a szimmetria-jelenségre építhető lehetséges tudásszociológia szerves fejezete is lehet) mindenekelőtt a fogalmi szimmetriák elemzésén kell alapulnia.

A fogalmi szimmetriák elemzése (elsősorban az egyes filozófiai rendszerekben és koncepciókban önmagukban, de kifelé haladó koncentrikus körökben már a különbözö tudományok elvi-elméleti megalapozásaiban is) elsöprő többséggel mutatja ki, hogy a fogalmi szimmetriáknak mind alaptípusai, mind azok származékos típusai (így a Hegel által kivételesen kultivált „reflexiós” fogalmak) olyan filozófiai viszonyokat sugallnak, amelyek „,valóságos viszony”-nak mutatják fel a fogalmi szimmetriákat.

A nyelvi és logikai rend e tapasztalat szerint általánosan és átfogóan, az egyes filozófiai rendszerek minősített eltéréseitől függetlenül nyúl át ezen a fogalmi rendszer által sugallt valóságkonstitúcióba.

A fogalmi szimmetria kritikai igényü kutatása, ha csak kezdeti formában is, de más tudományokból származik. Reinhart Koselleck Az aszimmetrikus fogalmak történeti-politikai szemantikája címü munkájában jelentékeny kísérletet tesz a fogalmi szimmetria-aszimmetria tudományelméleti vizsgálatára, elsősorban a történettudomány néhány fogalom-párjának a közelmúltban bekövetkezett és a kutatás számára máig relevánsnak megmaradó kompromittálódása miatt.

Amit Koselleck aszimmetrikus ellenfogalmaknak nevez (a civilizáció-barbárság fogalmainak példáján), voltaképpen a fogalmi szimmetria útján jönnek létre. A Koselleck idézte példák kezdetben mind klasszikus fogalmi szimmetriák (maga a civilizáció-barbárság fogalompár is szimmetrikus, hiszen a fogalompár egésze kitölti az emberiség fogalmának egész terjedelmét).

A szimmetria azonban, mint Koselleck találóan érzékelteti, a politikai, társadalmi praxisban aszimmetrikussá válik (hiszen a fogalompár két tagja közül az egyik minden tartalmi és értékbeli pozitívumot magában összpontosít, amíg a másik szemantikai finomságokkal már egyáltalán nem jelölhető egyértelmüséggel univerzális negatívummá, $\mathrm{s}$ amellett ugyancsak univerzális ellenségképpé válik).

Az így létrejövő aszimmetrikus fogalmak tehát nemcsak a szimmetrikus viszonyból jönnek létre, de maguk is elidegeníthetetlen részei a szimmetria-jelenségnek és a szimmetria-jelenség lehetséges tudásszociológiai kritikájának.

A fogalmi szimmetria kritikájának több problémakört kell felölelnie. Egyrészt foglalkoznia kell az önálló és tiszta formájú fogalmi szimmetriák problémájával, amelyek elsősorban az adott konkrét fogalom együttes, teljes kitöltésének és az adott fogalmi univerzum teljes kitöltéséből következő szimmetrikus megoszlású valóság-viszonyok kialakulását vizsgálnák.

Elválik ettől (bár ugyancsak maradéktalanul a fogalmi szimmetriák problémakörének része) az aszimmetrikus fogalmi viszonnyá váló fogalmi szimmetria, hiszen itt már nemcsak az a kutatás feladata, hogy kimutassa, hogy a „tiszta” fogalmi szimmetria a maga módján alakítja a valóságot, amennyiben a fogalmi szimmetria mögött kezdetben nem állnak „szimmetrikus” valóságos viszonyok, hanem már az is, hogy konkrétan mutassa ki az aszimmetrikus ellenfogalmak tartalmainak új szemantikáját, a módosult fogalomképzés történetét és annak okait. Az aszimmetrikus ellenfogalmak elemzése ki tudja mutat- 
ni, hogy az eredetileg szimmetrikus (tudásszociológiailag már problematikus) fogalmak nem kis részben már ismét léthezkötöttségi okokból válnak aszimmetrikussá.

Kelet felé haladva minden társadalom a maga fóvárosának keleti felét tekinti a Balkán kapujának. E nem éppen a tudományos szellem dezantropomorf magaslatait emlékezetünkbe idéző megfogalmazásban meghúzódó aszimmetrikus ellenfogalompár esetében nyilvánvaló, hogy önmagát (léthezkötötten) mindenki a civilizáció és nem a barbárság körébe sorolja, tökéletesen függetlenül attól, hogy egy határral arrébb (hasonló léthezkötöttségi motívumokból következően) már ő válik barbárrá. A szimmetria tudásszociológiája ezen a ponton újra találkozik a léthezkötöttségi paradigmával.

Célszerü megkülönböztetni az aszimmmetrikus ellenfogalmak áttételes léthezkötöttségétől eltérő közvetlen, vagy legalábbis nem oly mértékben áttételes léthezkötöttségi szimmetria- vagy aszimmetrikus ellenfogalmakat, amelyek az irodalomban, a politikában vagy éppen a társadalmi lét folyamataiban nap mint nap újra születnek.

Egy költő (az egyik legnagyobb példa erre éppen az európai romantika egyik egyetemes költője, Petőfi Sándor) kezdheti verseinek jó részét „önmaga” és a „világ” tökéletes és tökéletesen léthezkötött aszimmetrikus ellenfogalmakként való explicit meghatározásával. Egy politikus vagy politikai irányzat definiálhatja önmagát léthezkötöttségi alapon aszimmetrikus ellenfogalomként (,mi barbárok vagyunk").

A szimmetria esetlegesen kidolgozandó tudásszociológiájának egyik nagy problémakörét a szimmetria-viszony kreativitásának neveznénk. Megszokott logikánk szerint nem tudatosul bennünk, hogy egy szimmetria-viszonynak elismert reláció óhatatlanul dinamikus folyamatokat indít el. Ez sajátos kreativitás, ami nagyon sokáig öntudatlan is maradhat. Ebben az esetben a szó szoros értelmében öntudatlan intellektuális mozgásokról is beszélhetünk.

Ha egy konkrét térben két elem a szimmetria viszonyába kerül egymással, maga ez a viszony, az e viszonyként való elismertetés olyan mozgásokat indít el, amelyek irányukban kiegyenlítik, egyenjogúsítják a szóban forgó két elemet. Ennek van filozó-

Ha egy konkrét térben két elem a szimmetria viszonyába kerül egymással, maga ez a viszony, az e viszonyként való elismertetés olyan mozgásokat indít el, amelyek irányukban kiegyenlitik, egyenjogúsítják a szóban forgó két elemet. Ennek van filozófiai-fogalmi, de van társadalmi, szociális és kulturális változata is. Egy ilyen viszony egyetlen keretfeltétele az, hogy a két elem ugyanabban a rendszer-

\section{ben lehessen értelmezhetó.} fiai-fogalmi, de van társadalmi, szociális és kulturális változata is. Egy ilyen viszony egyetlen keretfeltétele az, hogy a két elem ugyanabban a rendszerben lehessen értelmezhetö.

A szimmetria-reláció immanens kreativitása nem önálló kauzális komponens, maga is számos egymástól eltérő kauzális sor kibontakozására épül. Nem önálló önszervező elv, nem is a pozitív metafizika egy válfaja, de az adott folyamat kibontakozásában részt vevő dinamikus kauzális sorok kölcsönhatásainak olyan általánosítható elvonatkoztatása, amelynek vizsgálatakor evidensen ki kell rajzolódnia annak a kauzalitásnak, ami a többi, azonosítható kauzális sortól független, önálló és kizárólag csak a szimmetria kreativitása által létrehozott kauzalitás. Ebben a fázisban a szimmetria-viszony érzékelése olyan sajátos differencia-mozzanat, amely bizonyító erejének belátása csak az adott kutatásnak abban a fázisában lehetséges, amikor a kutató nagy pontossággal meg tudja állapítani a valóban csak a szimmetria-viszonyhoz köthető önálló differencia-mozzanatot. 
Amikor valaki kihív valakit párbajra, a szimmetria-viszony kreativitása müködésbe lép, akkor is, ha a két párbajozó fél minden tekintetben különbözik is egymástól. Pontosan ezt a mozzanatot érvényesíti nagy müvészi hatással Krúdy Gyula számos, „A hírlapíró és a halál" tematikáját újrafogalmazó elbeszélésében, melyekben a hírlapíró győzi le az ezredest.

Amikor két csapat labdarúgó-mérkőzése örökrangadóként tárolódik a nézőközönség emlékezetében, a szimmetria-viszony kreativitása akkor is egy szintre emeli őket, ha amúgy igen eltérő játékerőt képviselnek.

Ha egy plurális pártrendszerben az egyik ellenzéki párt el tudja hitetni magáról, hogy ő a kormánypárt hiteles kihívója, a szimmetria kreativitása potenciálisan már az egyenrangúság attribútumával is felruházza.

Minden verseny, minden rivalitás meg-

Amikor valaki kihív valakit párbajra, a szimmetria-viszony kreativitása múködésbe lép, akkor is, ha a két párbajozó fél minden tekintetben különbözik is egymástól. Pontosan ezt a mozzanatot érvényesiti nagy múvészi hatással Krúdy Gyula számos, „A hírlapiró és a halál” tematikáját újrafogalmazó elbeszélésében, melyekben a hirlap-

iró gyózi le az ezredest.

Amikor két csapat labdarúgómérkózése örökrangadóként tárolódik a nézóközönség emlékezetében, a szimmetria-viszony kreativitása akkor is egy szintre emeli óket, ha amúgy igen eltéró

játékerót képviselnek.

Ha egy plurális pártrendszerben az egyik ellenzéki párt el tudja hitetni magáról, hogy ó a kormánypárt hiteles kihívója, a szimmetria kreativitása potenciálisan már az egyenrangúság attribútumával is felruházza. határozó elemévé válhat ez a kreativitás, miközben egy ilyen ítélet kimondása csak akkor lehetséges, ha annak az esetnek a vizsgálatában egyszerre rendelkezünk az összes meghatározó kauzális összetevő ismeretével, és ezen oksági sorok elemzésébe be tudjuk építeni a szimmetria kreativitásának önálló mozzanatát is.

A módszertani nehézség ezen a ponton keletkezik: reduktív eljárások nagy sorát kell elvégeznünk, amelyek végeredményeképpen végül önállóan elválik a szimmetria kreativitásának produktuma.

Nyilvánvaló, hogy a filozófiában e mozzanat reduktív kimutatása még annál is nehezebb feladatot jelent, mint a társadalmi és szociológiai szimmetria-viszonyok esetében. Ebben az esetben nemcsak olyan társadalmi aktorokkal van dolgunk, akiknek, akár tudnak, vagy nem tudnak arról, hogy a szimmetria kreativitásának terében tevékenykednek, szembe kell szállniuk akár magával a filozófussal is. A filozófiai szemantikának ráadásul megvan még az a tulajdonsága is, hogy az (a szemantika - K. E.) adott esetben a felvett szimmetria-viszonytól csak jelentős argumentációs távolságban legitimálja (visszamenőleg) a kiindulást. Ezért a már kimutatott szimmetria-viszony is nagyban veszíthet jelentőségéből, hiszen ha a gondolatmenet szemantikája egyszer már (visszamenőleg) igazolta saját magát, meglehetősen közömbös lehet az esetleges szimmetria-viszonyból való kiindulás.

Meg kell állnunk egy pillanatra Fichte gondolkodásánál, akinél a szimmetria-viszony különleges szerepet játszik. A számára történetileg adott módszertani vákuumban ugyanis ez helyettesíti mind az ismeretelméletet, mind a korábbi metafizikát, egybekapcsolván a kriticista filozófia Fichte által megértett és elfogadott változatát a fogalmi szimmetriák felértékelésével. 
Intenzív figyelmünkre érdemes a kifejezetten politikai szimmetria jelensége is. Az eltérő történelmi korok felsorakoztatásától eltekintve kiemelkedő fontosságúnak tünik napjaink plurális demokratikus politikai berendezkedésében.

Formális demokráciaelméleti szempontból (s ez a jelző itt nem negatív) látszólag a politikai szimmetria, ,a kétpártrendszer” egyáltalán nem tünik automatikusan problematikusnak. Ebben a nem-pejoratívan értett demokráciaelméleti formalizmusban a legitimáció megszerzésében az egypártrendszer (ami óhatatlanul a totalitarizmus valamelyik változatának tekinthető) elkerülése meghatározó. A valódi pluralizmus, illetve a valódi kétpártrendszer között nem szokás különbséget tenni. Ebben az egyenlő megítélésben jelent új típusú különbséget a szimmetria jelensége.

Egy társadalom valóságos politikai történéseiben az ilyen szimmetria létrejövetele, megszilárdulása, uralomra kerülése, majd valamilyen irányú megszakadása felismerhetetlenül olvad bele a hétköznapok eseményeibe. Az, hogy kezdetben sok, igen különböző párt van, majd hogy ezek különböző csoportosulásokra lépnek egymással, ezt követően pedig külön minőséget jelent az immár lecsökkent számú pártszövetségek harca, magától értetődő. Adott esetben éppen a koalíciókötés logikája zárja ki a további egyenrangú versenyből a harmadik és negyedik helyen álló pártot, hogy végül akár megkönnyebbülésnek is érezzék a megmaradt két párt kettősségét. Ezekben ekkor még felismerhetőek a társadalom számára az egykori valóságos pluralizmus körvonalai.

Ez az ív adott esetben akár egy vagy több évtizedet is igénybe vehet, amelynek következtében e folyamatok olyan mértékben is lelassulhatnak, hogy akár tökéletesen észrevétlenek is maradhatnak.

Amíg a 13 pártból 5 párt lesz, már el is felejtjük a kimaradó 8 párt vezetőjének nevét, $\mathrm{s}$ az a harmadik, aki a vezető két párt sikeres koalíciója miatt eljelentéktelenedik, inkább balszerencsésnek tünik szemünkben, mint a politikai egészet érő jelentős veszteségnek.

Abban a korszakban, amikor a két centrum felgyorsítja a kisebb tömörülések hozzájuk való csatlakozását, olyan, önmagában figyelemre ugyancsak nem méltatott jelenségek is fellépnek, mint a tartalmak homogenizál(ód)ása, az egyes árnyalatok radikális eltünése, a tartalmi ajánlások lényegtelenné válása, az egyéni különbségek leértékelödése, az addigi érdemek és teljesítmények elfelejtése.

Minden abban az új funkcionális rendben nyeri csak el értelmét, amelyet a két pólus markáns kialakulása már eleve kijelölt számukra.

A szimmetria-jelenség önálló „munkája” már itt tetten érhető, a két centrum azonosítható megjelenésének korszakában már szembesülhetünk a szimmetria erejével. Statisztikai lehetetlenség, hogy a kettős viszony megjelenésének korszakában ezek nagyságrendjüknél, intenzitásuknál, szervezettségüknél vagy más tulajdonságuknál fogva valóban egyenlők lehessenek. Ebben a fázisban nem a politikai aktorok teremtik meg a szimmetrikus viszonyt, hanem a szimmetria-viszony teremti meg a politikai aktorok kiegyensúlyozottságát. Lehet a két centrum egymástól bármilyen távolságban is, a szimmetria-viszony megjelenése potenciálisan pillanatok alatt egyenlő erejüvé teszi őket.

A legdrámaibb mozzanatot mégis attól a korszaktól érdemes datálni, amikor a két centrum erőviszonyai kiegyenlítődnek. Ettől kezdve már nem a szimmetria alakítja az aktorokat, de az aktorok viselkednek a szimmetria strukturális és logikai meghatározásai alapján.

A politikai demokrácia, a politikai mindennapok számtalan részletén áthatolva a már manifesztté váló, a kiegyenlítettséghez közel jutó szimmetria a politikában ugyanis nem más, mint testet öltött barát-ellenség-viszony.

Ebben a helyzetben minden akció, minden szó, minden tett a várható politikai haszon reményében immár abból nyeri végső legitimációját, hogy mennyit ér az „ellenséggel” vívott harcban. Nem kell ahhoz sem különösebb fantázia, sem a versengő felek túlzottan 
negatívnak beállított hozzáállása, hogy szembe kelljen néznünk azzal a ténnyel, hogy ez a harc, a maga belső logikájától vezettetve, kiléphet a klasszikus demokrácia medréből.

A politikai retorika ugyanettől a logikától vezettetve szélsőségessé válhat, de az sem kevésbé egyértelmü, hogy egy-egy döntő helyzetben várható nagyobb anyagi lehetőségek sem utasíthatóak el.

Ez a típusú politikai szimmetria, amelynek gyökerei a legdemokratikusabb helyzetben is létezhetnek, szinte saját logikáján fejleszti ki a demokrácián belüli türelmetlenséget, vagy egy, a demokrácián belül létrejövő kvázi-totalitarizmust, amelynek elméleti osztályozása jóval problematikusabb lehet, mint annak általános, mindenki által érzékelt valósága.

\section{Irodalomjegyzék}

Destutt de Tracy, A. (1970): Éléments d'idéologie. Vol. 1-2. Paris.

Foucault, M. (1969): L'Archéologie du savoir. Paris.

Friedrich, H. (1956): Die Struktur der modernen Lyrik. Hamburg.

Funke, M. (1974): Ideologie und ihre Ideologie bei Nietzsche. Stuttgart - Bad Canstatt.

Gabel, J. (1987): Mannheim et le marxisme hongrois. Paris.

Glass, K. és Serloth, B. (1996, szerk.): Mitteleuropaeische Mythen und Wirklichkeiten. Ausformungen Bedeutungen - Standortbestimmungen. Wien-Torun.

Kiss, E. (1992): Die Grundprinzipien des modernen Alltagsbewusstseins im Spiegel ihrer Geschichte. Prima Philosophia, 5. 3. sz. Juli-September. 279293.

Kiss, E. (1997): Reconstructing Positive Political Metaphysics. In: The European Legacy, 1. 6. sz. 2185-2198. DOI: 10.1080/10848779608579665

Kiss, E. (2006): Hendrik de Man and Attila József. On Soft and Hard Conditions of Socialism. The Euro- pean Legacy, 11. 5. sz. August. 515-526. DOI: 10.1080/10848770600842861

Koselleck, R. (1997): Az asszimetrikus ellenfogalmak történeti-politikai szemantikája. Budapest.

Koselleck, R. (2010): Begriffsgeschichten. Studien zur Semantik und Pragmatik der politischen und sozialen Sprache. Frankfurt am Main.

Lefebvre, H. (1968): La vie quotidienne dans le monde moderne. Paris.

Lukács, G. (1963): Die Eigenart des Ästhetischen Neuwied.

Mannheim, K. (1978): Ideologie und Utopie. 6. kiadás. Frankfurt am Main.

Scheler, M. (1980): Die Wissensformen und die Gesellschaft. Bern-München.

Topitsch, E. (1978): Vom Ursprung und Ende der Metaphysik. Wien.

Weyl, H. (1982): Szimmetria. Budapest. 